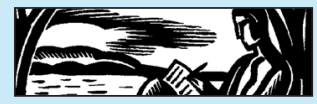

\title{
From Diaries to Blogs: Cultural and Political Networking in Russian Autobiographical Practice
}

\author{
Tatiana Saburova \\ Omsk State Pedagogical University, Russia \\ Nataliya Rodigina \\ Novosibirsk State Pedagogical University, Russia
}

\begin{abstract}
IN ENGLISH
We aim to reveal the transformations of the subject, structure, goals, and functions of autobiographical practice from diary to blog in Russia, its traditions and developments as a specific form of political and cultural networking. The proposed paper is based on the comparison of the diaries of Alexander Turgenev (1784-1845), a historian and journalist, and the blog of Boris Akunin (Georgii Chkhartishvili, 1956-), a writer, translator, historian. Turgenev's diaries were published as "Chronicle of a Russian" in reputable literary magazines and political journals in the 1830s and 1840s; they contributed to the formation of the intelligentsia and furthered cultural links between Russia and Europe. Akunin expresses his political views on his blog "Love of History," posting autobiographical notes, travelogues, reflections, correspondence, and photographs. Juxtaposing the diary and blog promises to yield rich insights into Russian cultural practices over time.
\end{abstract}

\section{ABSTRACT IN RUSSIAN}

В статье раскрывается трансформация предмета, структуры, целей и функций автобиографического письма в России, от дневника и переписки первой половины XIX века до интернет-блога начала XXI столетия, которые мы рассматриваем как особую форму создания политических и социальных сетей. Основные положения статьи основаны на сравнении дневников, писем историка и журналиста Александра Тургенева (1784-1845), и интернет-блога 
писателя, переводчика Бориса Акунина (Георгия Чхартишвили, 1956-). Дневники и письма А.И. Тургенева публиковались под названием «Хроника Русского» в известных литературных журналах 1830-40-х гг., став одним из факторов формирования интеллигенции и культурных связей между Европой и Россией. Борис Акунин выражает свои политические взгляды в своем блоге «Любовь к истории», публикуя автобиографические и путевые заметки, размышления, письма и фотографии. Предлагаемое сравнение дает возможность нового взгляда на развитие автобиографической практики в России и ее роли а формировании культурных сообществ.

Keywords: Russian intelligentsia, diary, letter, blog

In nineteenth-century Russia different forms of autobiographical writing, including diaries, became a widespread cultural practice of educated society, a way of self-definition, a tool of edification, and a means of cultural transfer, specifically, in the Russian-European dialogue and the construction of modernity. The diaries of the Russian intelligentsia were a means of conveying ideas, and were read and discussed in cultural "circles." Subsequently they were published in journals addressed to wide audiences, thus moving the private sphere of personal experience into the public space of political ideas and cultural values. This kind of public diary, which was in fact a chronicle of political and cultural life, could form a specific communicative space, a cultural network, strengthening the collective identity of social groupings.

Today the blog resembles this kind of public diary as a form of selfrepresentation, a tool of social construction and political mobilization through networking on the Web. We aim to reveal the transformations of the subject, structure, goals, and functions of autobiographical practice from diary to blog in Russia, its traditions and developments as a specific form of political and cultural networking. The proposed paper is based on a comparison of the diaries of Alexander Turgenev (1784-1845), historian and journalist, and the blog of Boris Akunin (Georgii Chkhartishvili, 1956-), a writer, translator, historian. Turgenev's diaries were published as "The Chronicle of a Russian" in reputable literary magazines and political journals in the 1830s-1840s; they contributed to the formation of the intelligentsia and furthered cultural links between Russia and Europe. Today, Akunin expresses his political views on his blog "A Love of History," posting autobiographical notes, travelogues, reflections, correspondence, and photographs. Juxtaposing the diary, letters and blog promises to yield rich insights into Russian cultural practices over time.

Scholars of autobiographical documents frequently examine the distinctive aspects of the diary as genre. Many scholars have commented 
on the uncertain situation of the diary. To use a recent statement, "the diary, as an uncertain genre uneasily balanced between literary and historical writing, between the spontaneity of reportage and reflectiveness of the crafted text, between selfhood and events, between subjectivity and objectivity, between the private and the public, constantly disturbs attempts to summarize its characteristics within formalized boundaries."

Turning to the diaries and correspondence of Alexander Turgenev, we note first of all the linkages and mixing of genres in his writing. The diary notes of the university period in Göttingen intermingle with letters to parents, brothers, friends while simultaneously serving as the foundations of his first journal publications. The letters to friends during his travels in Italy, Switzerland, and England and his long residence in France and German are widely circulated, read in circles of friends and salons, as well as published in literary journals. ${ }^{2}$ Thus, the diary entry, letter, or journal article might often correspond textually, in content but also in form; for example, a description of events in a letter to friends could resemble a diary annotation including date and time of entry, and in so doing distinctively structuring the text. Journal publications resembling intimate letters ("letters to close friends") gained wide popularity in Russia in the first half of the nineteenth century: Karamzin's Letters of a Russian Traveller, Chaadaev's Philosophical Letters, the correspondence between Belinskii and Gogol were a signal for Russian intellectual culture and literary development. Nora Buhks writes about the eighteenth century in Europe as an age of letters. "Letter-writing was on much the same footing as literary creation. The striving for thematic variety, for a witty, lively style and the vivid reflection of events, made letters into a kind of aristocratic chronicle, whilst the ever-growing tendency towards reflections and moralizing exhortations brought them close to the form of philosophical essays. At the same time letters were increasingly losing their intimate orientation, for through the tradition of reading them in salons, and of collecting and publishing them, the circle of their addressees widened. Public readings in brilliant salons, stylistically refined epistles by aristocratic writers, the passion for collecting letters, interest in their publication and, most important, a constant creative striving towards the literary perfection of letter-writing - all this was to occur in Russia a century later, in the first half of the nineteenth century." ${ }^{3}$

Letters and diary entries are similar in their communicative nature and function, and a present-day blog brings together the features of both. It shares with the diary the periodicity of its entries, the description of events in a chronological sequence, the specification of time and often the location of the author, a free structure and the personalized evaluation of events. With the letter the blog shares the designation of the 
recipient of the text, whether it be friends or, if it be open to the entire internet community, all who so desire; and the opportunities for response both from "real" and Internet "friends." As for the open letter designated for publication in a periodical or read in public, the blog is similar in the motivation for creation - the establishment of a communicative space of like-thinkers; the construction of one's own picture of the world and interpretation of ongoing events from the vantage point of that picture's distinctive elements/building blocks. In creating his blog, Boris Akunin positioned himself, firstly, as a writer, having designated a literary pseudonym rather than his own surname as his personal signature. We can posit that he was relying upon his own symbolic capital as an author of popular mysteries with a historical flavor in order to enhance his credibility as an evaluator of current events from a past perspective.

\section{THE FUNCTIONS AND ADDRESSEES OF TURGENEV'S LETTERS AND AKUNIN'S BLOG}

Turgenev's designated readers were primarily his friends, to whom he often directly speaks. In so doing his texts reflect the cult of friendship holding sway at the time and actually define the contours of a discrete circle of communication (letters addressed to a single friend, but meant to be read by a circle of friends, but then circulated more widely, and even published after minor editorial revisions). The letter was a source of information, but also a subject for conversation, a stimulus to intellectual and cultural activity. Letters ranged over important issues of both a societal and personal nature, creative projects and books read, and in so doing stimulated yet further intellectual endeavors: "I more and more as time passed by need to be with you, if not physically then at the very least in heart and mind, "in thought"....From now our correspondence must be both an important and even necessary part of our lives."

Turgenev wrote several letters a day, taking advantage of "the occasion" (passing them on with travelling friends and acquaintances), utilizing the diplomatic post as well as ordinary postal services, exploiting his longstanding friendship with the Bulgakov brothers (who oversaw both the Moscow and St. Petersburg post offices). This provided Turgenev with a reliable means of conveyance, but also an opportunity to bypass censorship. As Petr Viazemskii recalled, he corresponded with all who approached him, with his brothers, his friends and often even with strangers, with scholars, the clergy of all faiths, women of all ages; he was in correspondence with all of Russia, with France, Germany, England and more.

Akunin's blog, like most blogs, is actively situated in a contemporary cultural and political space, poised to combine a communicative and 
mobilizing function. Readers of the blog are viewed as potential virtual "friends" sharing defined world views and aesthetic values, and capable of realizing these views and values in society. Constructing the ideal type of a reader of his "live journal," Akunin includes in this grouping people "whose interests go beyond their own kitchen" ["extend beyond their own nose"], the "political nation." ${ }^{5} \mathrm{He}$ has in mind those of the population concerned to form their own opinion and have some impact on history. ${ }^{6}$

Certainly it is precisely one's stance towards the contemporary political situation in Russia that for Akunin is a primary category in constructing, imagining "his" audience. For this reason one of the first surveys he conducted of his readers concerned their political affiliations. All the more to his surprise, he discovered that only a quarter of them were at all interested in politics. In his commentary on this, he emphasized that it was politics above all that concerned him. Despite his own testimony that the specific political leanings of each of his readers was not of vital interest to him, he nevertheless periodically conducts surveys clarifying precisely this question. So, it is precisely the contours of one's political sympathies that for Akunin define Internet friendship, and only friends can post commentaries expressing their opinions on the topic under consideration. No less significant, Akunin clearly recognizes that behind the Internet nicknames are real people [or not] of real political involvement. In formulating his own stance to this or that political event in Russia, Akunin is cognizant of the opportunity to mobilize his blog "friends" to participate in real, peaceful political acts. This is clearly demonstrated by the following fragment of a posting devoted to the trial of Pussy Riot: "Given the absence of a normal court, normal parliament and normal elections, the little man has few means of combatting injustice. I can think of only two. The first is to protest over the internet, which many in fact zealously do, because it is easy. The second is also not very complicated, but far fewer people resort to it. To do so, you have to show up there where you cannot not be and show yourself. No virtually, but materially (corporally, in body). So, "he" is "I," not somebody on a Live Journal, not "somebody" on Facebook, but me, with my nametag, live, in person, because there was no other way to give expression to my beliefs." "

In contrast to the diaries and letters of Russian intellectuals of the early nineteenth century, contemporary Internet blogs posted by the liberal Russian intellectual elite are engaged not only in the formation of political and cultural networks but also in attempts to mobilize their interlocutors [or participants] in specific politics acts within the bounds of the existing legal framework.

A look at Turgenev's diaries and letters, and at Boris Akunin's blog allows us to identify yet another designated recipient of their texts the powers that be. From the early nineteenth century the relationship 
between the intelligentsia and the state was a topic of never ending discussion. In the first half of the century the intellectual elite, while keeping at a distance from the state, nevertheless entertained hopes that it would use its power to transform society, and considered it necessary to cooperate with authority, to carry out a dialogue. But from the middle of the century opposition to authority becomes a signal trait of the intelligentsia, reflecting not only one's radical political views but also a means of identifying that intelligentsia as a distinct group.

Early in the nineteenth century letters served, by means of perlustration, as a way of conveying public opinion to the authorities. Thus, Petr Viazemskii called the attention of Emperor Nicholas the first to the fact that he "always wrote openly....in the hope that our government, given the absence of independent instruments of public opinion, would find out by means of confiscated letters, what in fact people in Russia are thinking about." ${ }^{8}$ Correspondence, then, becomes not so much a private matter as one of public significance. Increasingly correspondence comes to resemble written opinion pieces on the day's most pressing issues, replete with philosophical commentaries and generalizations.

At the outset of the twenty-first century, with the acceleration of the pace of life, including its political side, and with the growing impact of mass media upon state and society relations, have come changes in the structure and content of the representations of authority, which we see in Internet blogs as well. Akunin openly expresses his opinion about the Putin regime, calling it the most corrupt in the entire thousand year history of Russia; one concerned only with the short-term interests of the ruling hierarchy, depriving the country of any future, and viciously dealing with its political opponents. In his view, as long as there are political prisoners in Russia there can be no cooperation with the reigning authorities. To him, the opposition between today's Russian state and liberal society is historically conditioned; he likens it to the Byzantine two-headed eagle. Moreover, he believes, state and society in Russia comprise two separate nations, the relations between which are defined by the binary opposition of "us" and "them." Each of these nations, inimically disposed to the other, has its own socio-cultural heroes. Society, understand as a synonym for the intelligentsia, has Chekhov, Mandelshtam, Pasternak, and Sakharov. The state has Ivan the Terrible, Stalin, Dzerzhinskii and Putin. This brings to mind the Herzen's phrase: "In Russia, all those who are readers hate the existing power structure; all those that love it never read anything at all."

In response to the persistent question first posed by Russians in the nineteenth century - what is to be done - Akunin, rejecting any acts of civil disobedience, argues in favor of applying growing pressure on an authoritarian regime to force change through honest elections at all 
levels of government. One can infer that one of the most accessible levers for applying pressure on the regime in his mind is through influencing public opinion in an open, effective manner, within the framework of existing laws pertaining to the actions of the authorities. It is revealing that as his blog has evolved, and the dynamics of Russia's internal political developments have unfolded, Akunin has become ever more pessimistic about the possibility of bringing about regime change in an open ("honest") manner.

\section{THE BASIC CONTENT OF TURGENEV'S DIARIES AND LETTERS AND OF AKUNIN'S BLOG}

First, Turgenev's diary conventionally provides precise information about events, meetings, circles of friends, mood and activities. Likewise, in these letters we observe the ongoing effort to inform friends about the political, cultural and intellectual life of Europe, which Turgenev observed in his frequent travels or periods of residence abroad. Then this information was published (as a rule, still in the epistolary genre) in journals published by Pushkin, Viazemskii, Polevoi and Pogodin. Turgenev was especially diligent about the timely publication of his correspondence, since such information about political events, theatre performances or literary novelties had a brief "shelf life," rapidly losing its significance. Turgenev regularly made entries, short notations in his diary in order to remind himself to include these items in his subsequent letters, in which he provided far more detailed and weighty descriptions of and reflections on the day's events. Alexander Turgenev led a very active life abroad, frequently attending lectures and sermons, visiting salons, sessions of the academy or parliament, museums and galleries. The intensity and saturated nature of his days is reflected in his diaries and letters, prompting him to muse upon the frenetic pace and richness of European life. The perception of Europe as a different cultural space, one of enlightenment and freedom, especially characteristic of many Russian intellectuals of the time, is woven through the extensive correspondence of Turgenev. Indeed, he treated life in terms of cognitive, intellectual and cultural activity, and the level of enlightenment and education as the primary indicator of civilizational development and freedom. Frequently we find comparisons of the rich cultural life of Europe with that of Russia; such comparisons reflect the continuing weight of the "mental map" of the Enlightenment in the mindset of Turgenev and friends. Just one example - Paris: "Here I have come alive; little by little my soporific state is being dissipated and the mind's activities refreshed; I don't have a moment free from dawn to 
dusk and beyond. I don't even have time to catch the rush of life in my journal...sermons, plays, musical performances, salon gatherings, libraries, so I don't let anything get by me." 10

In this passage we also see clearly the main topics embedded in his correspondence from Paris. The themes of his diaries and letters, and subsequently of his published "Chronicles of a Russian" - we note the label "chronicle" attached to the series of publications, referring us back to the diary - highlight the political, literary and cultural life of Paris at the time. With increasing frequency, the thirst of Russian educated society for information about books, articles, literary and scientific events, was being satisfied by the appearance of special sections in journals devoted to these topics with entries by permanent correspondents such as Turgenev. Such descriptions of European cultural life often served as a platform for the expression of Enlightenment ideals, a way to emphasize the importance of promoting such ideals. William Mills Todd argues that familiar letters played an important role in the dissemination and social acceptance of enlightenment ideals, which hold that civility and learning necessarily lead to social progress. ${ }^{11}$

Politics occupies a significant place in Turgenev's correspondence; above all issues related to the promotion of human rights and freedom, of parliamentarianism in Europe, since liberal inclinations were widespread among the Russian intelligentsia of the time. Constitutions, representative government, emancipation, were all at the center of political debate. The notion of a "free Europe," which had undergone a series of revolutions, was an important component in the Russian intelligentsia's thinking about the prospects for freedom in their own country. Comparisons with Europe were central to the philosophy of history in Russia - the idea of Russia as a part of Europe - but also fundamental to projects of political reform.

Comparison between Russia and Europe, a traditional element of the intelligentsia autobiographical letter, continues to this day, and is present in Akunin's blog as well. However for him, in contrast to Russian intellectuals of the nineteenth century seeking to establish their own national identity, Russia's inclusion in European civilization is no long an issue, needing corroboration. Indicative of this is his comment: "After all, there are people who still grumble about the corrupting influence of the West! Did you know that Love is an imported product, brought to Russia only a dozen generations ago and only slowly taking root in our soil?" 12 The shared culture and history of Europe and Russia is something he takes for granted, and for that reason the majority of his postings about this or that development in Russia's past or present are framed within the context of European events. In his narrations of the history of sailing ships, 
about the best children's literature, about "remarkable" evil-doers, the people and events of the past are presented tandem with analogous Russian developments. An ecstatic description of the Russian church Pokrov on the Nerli is juxtaposed to an enthusiastic description of a French fresh air museum. Many dramatic tales of his compatriots unfold equally in both Russian and European settings, underscoring the idea that Russia is but a part of Europe.

However, Akunin's acknowledgement of the historical inevitability and advantages of Russia's "Western" socio-cultural and political vector by no means precludes him from reflections upon Russia's uniqueness [самобытность]. Like some intellectuals of the nineteenth century Akunin, portraying Russia as a European country, nevertheless calls attention to its uniqueness. In the ongoing discussion about Russia's strengths and weaknesses, Akunin positions himself as an expert, organizing a series of surveys of his readers, and analyzing the results. Drawing upon the results of such surveys, Akunin lists as the "strong sides": 1) a rich cultural stratum, because of which Russia has made major contributions to world literature, science, music and painting; 2) its multi-national nature (which, by the way, can be listed on both the "strong" and "weak" sides of the ledger); 3) "two nations in one"; that is, the intelligentsia and the people; 4) abundant natural resources; a plus which turns into a minus when the government survives by the extracting raw materials alone, with no concern for the future; 5) the advanced level of education of the population; 6) the country's strong literary inclinations; 7) the people's common sense; it's hard to fool the people because they believe in no-one. As the primary deficiency of the Russian population Akunin to the lack of a sense of self-esteem, of one's own personal worth. ${ }^{13}$ It is precisely that quality - a sense of self-worth, that is the best gauge of the level of civilization. (We recall that for Turgenev it was the level of enlightenment as well as the degree of personal freedom.)

Returning then to Turgenev, notions of progress, enlightenment and freedom are inextricably interwoven in his understandings. The notion of gradual societal progress (in contrast to revolutionary transformation), the hope of reform from above (by a constitutional or enlightened monarch), a belief in the central role played by education and science in societal development - all of these were frequent themes to be found in his diaries and letters. As noted earlier, the above values, which we associate with a liberal world view, are also shared by Akunin. His blog, indeed, is intended to promote just such beliefs.

Turgenev also displayed a keen interest in religion in France, an interest spurred by his long service in the Department of Spiritual Affairs of Foreign Confessions in Russia, the attention he devoted to the various 
confessions, their status and the interrelations of different faiths. We also note that for the Russian intelligentsia the problem of religious belief was important in the context of their ongoing spiritual quests, of their dissatisfaction of some with the role of the Orthodox Church in society, and of their pondering over the legacy of European culture (including its religious component.) The latter found expression in the spread of mysticism in the reign of Alexander I, conversion to Catholicism, and the emergence of Russian religious philosophy.

In Akunin's blog, the separation of church and state is one of his firm demands, the "minimal program of a normal human being." However, on occasion we meet in his blog piquant musings about "the other side" and "the end of the world." 14 As a rule, the author deploys eschatological subjects in order to shed light on Russian national character, and usually with a light, ironic touch. Turgenev's diaries and letter often take on the character of a travelogue, something conditioned, of course, by his constant travels/wanderings but also in response to the popularity of the genre of travellers' journals in Russian culture; this, in turn stemmed both from the influence of European literary models and the widespread practice itself of travel by Russians. Just notice that the distinctive aspects of the Russian travelogue have been superbly illuminated by the work of Andreas Schonle. ${ }^{15}$ "Turgenev persistently included in his note taking everything of interest he observed (museums, libraries, picture galleries, historical monuments) and while doing so, included detailed descriptions, a verbal portrait of what he had seen, transporting the reader to a different place. Although this brings up the logical question of what criteria he used to select events for inclusion in his "Russian Chronicle," how he determined their significance both for the development of European culture and the interests of Russian society. On the one hand, he practically directed potential travellers as to what to see, where to go, what to do in a town, laying out in detail his own pathways, with all the stops identified, including even detail on how long each leg of the trip would take, and how to travel. On the other hand, in the tradition of Stern and Karamzin, Turgenev gave considerable space to his own experiences, feelings and emotions provoked by visiting this or that site, by works of art or natural landscapes.

But Turgenev's diaries, letters and published "chronicle" are notable not only because they are saturated with information, by the desire to record and convey to Russia everything going on in the cultural life of Europe. An inseparable part of Turgenev's texts was his description of visits, meetings, conversations, etc; his depicting of the communicative space and portrait of a defined "interactive network" linking the worlds of European and Russian intellectual correspondence. Michail Pogodin 
provided the following impression of him: "French ministers confided in him their fears about the fate of the ministerial system; the English talked with him about remaking Parliament; German professors slipped him information about communism; he brought French abbots Orthodox treatises, and informed members of the Holy Synod about the publications of the new German thinkers." ${ }^{16}$ Turgenev also acted as an intermediary in the correspondence between Schelling and Chaadaev, and facilitated the dissemination of Schelling's ideas in Russia. He was a constant correspondent with Chateaubriand, Guizot, Thierry, Mignet. Alexander Herzen wrote of Turgenev: "Turgenev - he was a lovely chatterbox; it was amusing to see how he, despite his grey hair and years, was vitally interested in everything human; how much life and energy he had! And then it was so engaging to listen to his wide-ranging stories, about his acquaintance with all the most celebrated people in Europe. Turgenev was a European gadabout, who could narrate everything, describe everything, be witty, laugh heartily, write his letter..."17 But it is important to note that in his correspondence and diaries he precisely identifies the names of all of his interlocutors, the subjects of every conversation, the opinions expressed. Thus the description of communicative practices became a permanent aspect of his written texts, both reflecting significance of oral communication, and establishing the boundaries of a real intellectual community. At the same time, for Turgenev it was important to "include" the Russian reader of his diaries and correspondence in that same communicative, cultural space to which he himself belonged; after a description of his meetings, conversations, visits to salons, he would seek to make his Russian audience "participants" or observers of his dialogues.

Turgenev's diaries and letters clearly register the distinct emotional tone of the era, the weight given to the emotions. Elaborate descriptions of feelings and emotions experienced are present in diary entries, as they are in general in such texts at the time. Such entries were part and parcel of the process of self-education, self-development, of the formation of identity. Emotional self-examination was an indicator of the influence of sentimentalism and romanticism - among Turgenev's favorite writers were Goethe, Byron, Zhukovskii - of the partial transfer of epistolary literary models, but also of a specific system of values, in which powerful thoughts were equated with powerful feelings. The influence of Voltaire can also be seen in the commingling of thought and feeling as two key categories; thus, the persistence of the Enlightenment paradigm in the consciousness of the nineteenth century Russian intelligentsia. Memoirists of this time often noted how richly emotional communication was; the use of "warm-hearted" epithets, reference to "flaming" feelings; "fires of the soul" and an "overheated life." 
Akunin's blog "preserves" the emotional saturation and desire to make the reader a participant in what is being described in the autobiographical rendition of events characteristic of the early nineteenth century. His thematic postings display a variety of feelings and emotions; love, hatred, pity, empathy, exhilaration, irony and sarcasm. The names of his postings make this clear: "More about love"; "Why does misfortune happen to people"; etc. Riddles, most commonly along the theme of mystery stories, surveys about a wide range of themes, including politics and daily life, are ways in which Akunin draws his readers into his emotional and intellectual space. Contests occasionally sponsored by Akunin seeking to establish, for example, who can produce the most entertaining life episode, motivate his readers to contribute to his blog. The emotional effect is heightened by posting photographs, reproductions of painting, book jackets, smiley emoticons, and clips.

A cardinal feature of diaries and letters is their temporality, reflecting the current notions of time and shaping the structure of the diaries and letters. Stuart Sherman has also linked the "temporality" brought into being by developments in clock- and watch-making in the second half of the seventeenth century to prose structures appearing at the same point in time. ${ }^{18}$ Time as a category is a prominent feature of Turgenev's writings. In the first place we are talking about historical time. He reflects upon the distinctive features of various historical epochs, the time line of history, the progress of history - here an important role was played by his time spent in archives and libraries in search of sources on the history of eighteenth century Russia, an activity which preoccupied him after his retirement from government service. In fact, a professor of Göttingen University, Andreas Schlözer foresaw for him a brilliant academic career as a historian. That time, of course, was one which witnessed a heightened interest in history, especially of Russia, a development connected with the emergence of Russian national consciousness. Not for nothing did Belinskii characterize "our nineteenth century" as framed by history, historical consciousness. For that reason, the presence of historical themes in Turgenev's works does not seem out of place, and is even typical for the writings of Russian educated society at the time, permeated as it was with an interest in history. Indeed, Jochen Hellbeck writes that there does seem to be a particular link between the diary and the type of historicist subjectivity first propounded by the founding generation of the Russian intelligentsia. ${ }^{19}$ The past is a constant presence in Turgenev's correspondence; the transition from past to present and the passing of time are prominent in his diaries entries, as is his imagining of the future. Just so, Irina Paperno writes that the matrix of a calendar grid provided by the diary "invites the diarist to deal with the past as he/she interacts 
with the present." She adds: "the diary mold also prepares the space for the unknown future." ${ }^{20}$

Second, we have personal, individual time, marked by years, months, days and minutes, the time of a trip, of meetings, conversations, readings. Turgenev often precisely notes the time of events, such that a friendly letter begins to resemble a diary entry, with time spent on the road or engaged in one or another activity noted. He could mention the time when writing a letter, or at what hour this or that event took place. Turgenev's time is circumscribed by events, measured not only chronologically but also by changes in place or activity. Time is a subject of reflection, and the growing value ascribed to time, the apperception of its rapid passage linked also with changes in the way of life, point to a temporality of modernity here.

Akunin's blog allows us to talk about the author as "a historical personage" cognizant of his "time and place" in the history of his kind, of his homeland, and of his personal responsibility for the fate of Russia. "Love of History" is the name of his blog. The signposts of history reflect the fate of his family, above all his parents, but also his own personal trajectory. In his case the status of a "historical individual" is manifested through his personal appropriation of history, his self-understanding, and likewise understanding of his ancestors and contemporaries as subjects of the historical process. The way historical awareness is represented in his blog, and what sites of memory are identified as most important for building a virtual community of real people, are revealed by the following blog entry: "In Russian history there are a number of glorious dates: May 9, April 12, February 19, and August 26. All of these dates: victory over the Nazis, the conquest of space, emancipation of the serfs, and the victory at Borodino...I have received as my inheritance. My own contribution there is lacking. A different matter - August 19. I personally didn't achieve any heroic feats on that day either. But it was my Moscow that stood up to the tanks. It was my generations that refused to fall backwards into that swamp of stagnation. It might well be that those are the only two real contributions of my city and my generation." ${ }^{21}$

Like Turgenev, who called himself a firm believer in progress and slow necessary changes, Akunin calls himself a positivist and believes that history enables us to predict the future. He expresses the hope that the attention he gives to the history of little known people, to the history of love, treachery, vulgarity, but also of heroic deeds (of self-sacrifice), will provide people living in the here and now with the opportunity to make value judgments themselves and to draw from history personally meaningful lessons. It is no surprise then, that his most recent writing project is the publication of a 
series of popular histories targeting people who feel the need to know "their own" yesterday, and to better understand both "today" and "tomorrow."

Turgenev's diaries and letters, as well as Akunin's blog, also fulfill an important function related to identity formation. The authors can be described as Russian Europeans, cosmopolitans, which duly underscores the breadth and latitude of their views, their devotion to the values and ideals of European culture. At the same time, both of our heroes believed it important to retain their national identity despite their long sojourns abroad (or maybe because of these long stays, because situation in a different cultural space often actualizes or reinforces one's national self-identification). No accident it is that Turgenev wrote, "like it or not I belong to Russia, to its history, its internal life, its prophets, its deficiencies and calamities, its praise and glory. I am, after all, a Russian, but still...."22 The title "Russian Chronicle," given to his journal, also underscores the importance he gave to his national identity. Almost two centuries later Boris Akunin writes in his blog: "I want to live at my home, my Russia, but I don't want my Russia to be vulgar. That and only that." 23

The diary could act as a source for reinforcing identity, especially for Russian intellectuals living abroad, while letters acted to formulate national and cultural identity for the intelligentsia as a group, a process gaining force in Russia in the first half of the nineteenth century, as the intelligentsia emerges as a cultural elite conscious of its role in society, and creating a specifically intellectual discourse. In the early twenty first century such functions of identity formation and consolidation have migrated to the blog, which combines the essential content and structural characteristics of the Russian autobiographical practice of the early nineteenth century. We note too, in conclusion, the eternal "cursed questions" of the Russian intelligentsia about the nature of power, the people, enlightenment and freedom, reside firmly in the various genres of autobiographical text we have reviewed, and remain embedded in the discourse of the Russian intelligentsia today.

\section{WORKS CITED}

Buhks, Nora. "The Role of the Everyday Letter in the Development of Russian Sentimental Prose of the Late Eighteenth Century.” The Modern Language Review 80.4 (Oct., 1985): 884-889.

Hellbeck, Jochen. "The Diary between Literature and History: A Historian's Critical Response." Russian Review 63.4 (Oct., 2004): 621-629.

Paperno, Irina. "What Can Be Done with Diaries?" Russian Review 63.4 (Oct., 2004): 561-573.

Schonle, Andreas. Authenticity and Fiction in the Russian Literary Journey, 1790-1840. Cambridge: Harvard University Press, 2000. Revised Russian translation: Podlinnost' $i$ vymysel $v$ avtorskom samosoznanii russkoi literatury puteshestvii, 1790-1840. St. Petersburg: Akademicheskii proekt, 2004. 
Sherman, Stuart. Telling Time: Clocks, Diaries, and English Diurnal Form, 1660-1785. Chicago/ London: University of Chicago Press, 1996.

Todd III, William Mills. The Familiar Letter as a Literary Genre in the Age of Pushkin. Evanston, IL: Northwestern University Press, 1999.

Turgenev, Alexander. Khronika Russkogo. Moscow: Leningrad, 1964.

Turgenev, Alexander. Politicheskaya proza. Moscow, 1989.

\section{ABOUT THE AUTHORS}

Tatiana Saburova is a Professor of History at Omsk State Pedagogical University. She completed a higher doctorate in History in Omsk in 2006. Her monograph Mythologies of the Russian Intellectual World: Socio-Cultural Representations of the Russian Intelligentsia in the Nineteenth Century was published in 2005. She had a scholarship at DHI in Moscow (2012) and was a Visiting Scholar at Tübingen University (2013), Indiana University, USA (Fulbright, 2011) and the University of Freiburg (DAAD, 2010, 2012). Tatiana Saburova is a member of Russian Society for Intellectual History, International Auto/Biography Association, and a member of the editorial board of "AvtobiografiЯ," Journal on Life Writing and the Representation of the Self in Russian Culture (Padova University Press). Her current research focuses on the identities and strategies of behavior of the Russian intelligentsia in the Late Imperial Russia, generations and historical memory.

Nataliya Rodigina is a Professor at the Department of Russian History, Novosibirsk State Pedagogical University, Russia. Her higher doctorate was completed in 2006 on the subject 'The Image of Siberia in Russian Journals in the Second Half of the Nineteenth Century' and was published as a monograph under the title 'Another Russia' (2006). She is a member of Russian Society for Intellectual History, International Auto/Biography Association, and a member of the editorial board of "AvtobiografiЯ," Journal on Life Writing and the Representation of the Self in Russian Culture (Padova University Press). Her research interests include life writing in the nineteenth and twentieth century Russia, the history of childhood and journalism in Russia. Nataliya Rodigina is also an affiliated researcher at the Tobolsk Science Station of the Ural Branch of the Russian Academy of Sciences.

\section{NOTES}

1 Paperno Irina, What Can Be Done with Diaries? Russian Review, Vol. 63, No. 4 (Oct., 2004), p. 561.

2 Turgenev Alexander, Khronika Russkogo. Moscow, Leningrad, 1964.

3 Buhks Nora, The Role of the Everyday Letter in the Development of Russian Sentimental Prose of the Late Eighteenth Century, The Modern Language Review, Vol. 80, No. 4 (Oct., 1985), p. 888.

4 Pis'ma Zhukovskogo k Turgenevu. Moscow, 1895. P. 71.

5 Akunin Boris http://borisakunin.livejournal.com/63488.html. Website accessed Feb. 2013 and seq. 
6 Akunin Boris http://borisakunin.livejournal.com/72429.html. Website accessed Dec. 2012 and seq.

7 Akunin Boris http://borisakunin.livejournal.com/72429.html. Website accessed Dec. 2012 and seq.

8 Viazemskii Petr, Collection of works, St. Petersburg, 1879, Vol. 2.P.105.

9 Akunin Boris http://borisakunin.livejournal.com/84854.html. Website accessed Feb. 2013 and seq.

10 Ostaph'evskii archive of Vyazemskii. St. Petersburg, 1899. Vol. 3. P. 264.

11 Todd III William Mills. The Familiar Letter as a Literary Genre in the Age of Pushkin. Evanston, IL: Northwestern University Press, 1999.

12 Akunin Boris http://borisakunin.livejournal.com/64897.html. Website accessed Feb. 2013 and seq.

13 Akunin Boris http://borisakunin.livejournal.com/77808.html. Website accessed Feb. 2013 and seq.

14 Akunin Boris http://borisakunin.livejournal.com/73652.html. Website accessed Mar. 2013 and seq.

15 Schonle Andreas Authenticity and Fiction in the Russian Literary Journey, 1790-1840 (Cambridge: Harvard University Press, 2000). Revised Russian translation: Podlinnost' i vymysel v avtorskom samosoznanii russkoi literatury puteshestvii, 1790-1840 (St. Petersburg: Akademicheskii proekt, 2004).

16 Turgenev Alexander, Politicheskaya proza, Moscow, 1989. P. 9.

17 Herzen Alexander, Collection of works. Moscow, 1954. Vol. 2. P. 242.

18 Sherman Stuart, Telling Time: Clocks, Diaries, and English Diurnal Form, 1660-1785. Chicago/London: University of Chicago Press, 1996.

19 Hellbeck Jochen, The Diary between Literature and History: A Historian's Critical Response, Russian Review, Vol. 63, No. 4 (Oct., 2004), p. 624.

20 Paperno Irina, What Can Be Done with Diaries? Russian Review, Vol. 63, No. 4 (Oct., 2004), p. 572.

21 Akunin Boris http://borisakunin.livejournal.com/72702.html. Website accessed Aug. 2013 and seq.

22 Turgenev Alexander, Politicheskaya proza. Moscow, 1989. P. 226.

23 Akunin Boris http://borisakunin.livejournal.com/86273.html. Website accessed Sept. 2013 and seq. 